\title{
Pulsed Electric Fields-Assisted Extraction of Valuable Compounds From Arthrospira Platensis: Effect of Pulse Polarity and Mild Heating
}

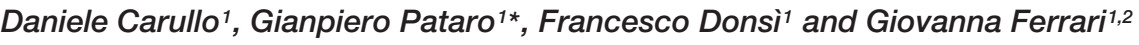 \\ ${ }^{1}$ Department of Industrial Engineering, University of Salerno, Fisciano, Italy, ${ }^{2}$ ProdAl Scarl - University of Salerno, Fisciano, \\ Italy
}

OPEN ACCESS

Edited by:

Eugene Vorobiev,

University of Technology

of Compiègne, France

Reviewed by:

Nikolai I. Lebovka,

Institute of Biocolloidal Chemistry

(named after F.D. Ovcharenko),

Ukraine

Luis Manuel Redondo,

Lisbon Higher Institute of Engineering

(ISEL), Portugal

*Correspondence: Gianpiero Pataro gpataro@unisa.it

Specialty section:

This article was submitted to

Bioprocess Engineering,

a section of the journal

Frontiers in Bioengineering and

Biotechnology

Received: 12 April 2020

Accepted: 14 August 2020

Published: 04 September 2020

Citation:

Carullo D, Pataro G, Donsi F and

Ferrari G (2020) Pulsed Electric

Fields-Assisted Extraction of Valuable

Compounds From Arthrospira

Platensis: Effect of Pulse Polarity

and Mild Heating.

Front. Bioeng. Biotechnol. 8:551272.

doi: 10.3389/fbioe.2020.551272
The present study aimed to investigate the effect of the main pulsed electric field (PEF) process parameters on the cell damages of $A$. platensis microalgae and the extractability of valuable compounds [water-soluble proteins (WSP), C-phycocyanin $(\mathrm{C}-\mathrm{PC})$, and carbohydrates $(\mathrm{CH})]$. Aqueous microalgae suspensions $(2 \%, \mathrm{w} / \mathrm{w})$ were PEF-treated at variable field strength $(E=10,20,30 \mathrm{kV} / \mathrm{cm}$ ), total specific energy $\left(W_{\top}=20,60,100 \mathrm{~kJ} / \mathrm{kg}_{\text {susp }}\right)$, and inlet temperature $\left(25,35,45^{\circ} \mathrm{C}\right)$, with either monopolar or bipolar square wave pulses ( $5 \mu \mathrm{s}$ of width, delay time between pulses of opposite polarities $=1,5,10,20 \mu \mathrm{s})$, prior to extraction with water at room temperature $\left(25^{\circ} \mathrm{C}\right)$ for up to $3 \mathrm{~h}$. High-pressure homogenization $(\mathrm{HPH})$ treatment $(P=150 \mathrm{MPa}, 3$ passes) was used to achieve complete cell disruption to quantify the total extractable content of target intracellular compounds. Scanning electron microscopy (SEM) and optical microscopy analyses clearly showed that PEF merely electroporated the membranes of algae cell, without damaging the cell structure and forming cell debris. The application of PEF treatment (monopolar pulses, $20 \mathrm{kV} / \mathrm{cm}$ and $100 \mathrm{~kJ} / \mathrm{kg}_{\text {susp }}$ ) at room temperature significantly enhanced the extraction yield of WSP [17.4\% dry weight (DW)], $\mathrm{CH}$ (10.1\% DW), and C-PC (2.1\% DW), in comparison with the untreated samples. Bipolar pulses appeared less effective than monopolar pulses and led to extraction yields dependent on the delay time. Additionally, regardless of pulse polarity, a clear synergistic effect of the combined PEF $\left(20 \mathrm{kV} / \mathrm{cm}\right.$ and $\left.100 \mathrm{~kJ} / \mathrm{kg}_{\text {susp }}\right)$-temperature $\left(35^{\circ} \mathrm{C}\right)$ treatment was detected, which enabled the extraction of up to $37.4 \%$ (w/w) of total WSP, $73.8 \%$ of total $\mathrm{CH}$, and $73.7 \%$ of total C-PC. Remarkably, the PEF treatment enabled to obtain C-phycocyanin extract with higher purity than that obtained using $\mathrm{HPH}$ treatment. The results obtained in this work suggest that the application of PEF combined with mild heating could represent a suitable approach for the efficient recovery of water-soluble compounds microalgal biomass.

Keywords: Arhtrospira platensis, pulsed electric fields, pulse polarity, temperature, extraction, water-soluble compounds, energy efficiency 


\section{INTRODUCTION}

Arthrospira platensis, commonly known as spirulina, is a cyanobacterium widely used for biotechnological applications. It is a multicellular and filamentous blue-green alga with helical shape (trichomes of 50-500 $\mu \mathrm{m}$ in length, and 3-4 $\mu \mathrm{m}$ in width) and represents one of the richest sources of proteins of microbial origin [55-70\% dry weight (DW)]; besides, it also contains significant amounts of carbohydrates (13-16\% DW), lipids (6-10\% DW), vitamins, and minerals (Lupatini et al., 2016). In particular, A. platensis is an excellent source of C-phycocyanin (C-PC), a water-soluble pigmented protein, which has gained importance in many applications in the food, cosmetic and pharmaceutical sectors, thanks to its blue color and its therapeutic properties, as well as for its potential use as a fluorescent marker in biomedical research (Fernández-Rojas et al., 2014). In A. platensis, C-PC serves as a light-harvesting pigment for the photosynthetic activity of this cyanobacteria, in which it is assembled, along with other phycobiliproteins, in the thylakoid membranes of chloroplast (Martinez et al., 2020), and may represent more than $20 \%$ of its dry weight (Martinez et al., 2017).

In general, the recovery of intracellular compounds of interest from algal biomass via conventional solvent extraction techniques is hampered by the presence of the rigid cell wall and membranes, which act as a barrier that greatly limits the penetration of the solvent into the cytoplasm and the diffusion of the solubilized intracellular compounds during the extraction process (Martinez et al., 2020). For these reasons, to recover a substantial amount of valuable compounds, the conventional extraction techniques may require the use of a large amount of solvent, long extraction time and relatively high temperature that may cause losses of labile compounds, as well as lead to the co-extraction of undesirable components (Günerken et al., 2015; Poojary et al., 2016). Moreover, the extraction process is often conducted upon drying of algae biomass, which requires a significant amount of energy and may cause thermal degradation of valuable compounds (Günerken et al., 2015; Golberg et al., 2016). In this regard, it has been reported that the initial amount of C-PC in A. platensis decreased by approximately $50 \%$ after the drying of the algae biomass (Martinez et al., 2017).

In light of these drawbacks of conventional solvent extraction methods, cell disruption pre-treatment of wet biomass that causes weakening or breakage of cell envelops is required to intensify the extractability of specific intracellular compounds with reduced energy consumption, while preserving or improving the quality (purity) of the extracts (Poojary et al., 2016). Among the cell disruption methods, freeze/thawing cycles, sonication, bead milling, and high-pressure homogenization $(\mathrm{HPH})$ treatments have been widely studied as pre-treatment of either microalgae and cyanobacteria biomasses, due to their ability to induce complete cell disruption, which markedly increases the extraction yield of the components located within the algae cells. However, all these methods cause the non-selective release of intracellular compounds, with the concurrent dispersion of cell debris or other impurities into the extraction medium, hence decreasing the quality of the extracts and complicating the subsequent downstream purification operations (Aouir et al., 2015; Poojary et al., 2016; Martinez et al., 2017; Carullo et al., 2018; Jaeschke et al., 2019).

In this frame, pulsed electric fields (PEF) is considered to be a very promising technology for mild and scalable cell disruption of wet biomass, thus avoiding the need for energyintensive drying and the consequent losses of labile compounds (Carullo et al., 2018). The technique consists of exposing fresh algae suspensions to repetitive high-intensity electric field pulses of short (of the order of $\mu s$ ) duration that cause the permeabilization of cell membranes by electroporation. This improves the efficiency of the conventional extraction process of valuable compounds from algae biomass, facilitating the penetration of the solvent into the cells and the selective release of intracellular matter (Poojary et al., 2016) without the formation of cell debris (Martinez et al., 2017; Phong et al., 2017; Carullo et al., 2018; Pataro et al., 2019). Recently, several studies have demonstrated the potential of PEF to intensify the extraction yield of target intracellular compounds, such as lipids, pigments, carbohydrates, and proteins, from different microalgae and cyanobacteria (Goettel et al., 2013; Zbinden et al., 2013; Grimi et al., 2014; Luengo et al., 2015; Parniakov et al., 2015a,b; Carullo et al., 2018; Geada et al., 2018; Silve et al., 2018), even though, to date, only a few works focused on A. platensis (Aouir et al., 2015; Martinez et al., 2017; Jaeschke et al., 2019).

However, it has been shown that the recovery of substantial amounts of compounds of relatively high molecular weight (e.g., protein) could require the application of intense PEF processing conditions (high field strengths and energy input), especially in the case of "hard-structured" microalgal cells (Postma et al., 2016; Pataro et al., 2019). Therefore, to reduce the operative costs and to maximize the extraction efficiency of high-added-value components, the use of PEF in a hurdle approach has been suggested. For example, several studies have demonstrated that the combination of PEF with moderate heating decreases the critical electric field required to cause electroporation in both microbial and algae cells, thus resulting in additive or synergistic effects in microbial inactivation or extraction of intracellular compounds (Saldaña et al., 2014; Timmermans et al., 2014; Luengo et al., 2015; Postma et al., 2016; Martinez et al., 2017). However, as per the literature survey, only Martinez et al. (2017) described the effect of temperature $\left(10-40^{\circ} \mathrm{C}\right)$ on the release of C-PC during $\mathrm{PEF}$ treatment of $A$. platensis, using a batch chamber equipped with a temperature control system.

Additionally, the use of bipolar pulses, which appear to be more efficient than monopolar ones, could be also suggested to obtain the required permeabilization effect with less severe processing conditions or to achieve higher efficacy at the same treatment intensity. Nevertheless, very few works have dealt so far with the influence of pulse polarity on the extent of electroporation of biological cell, and only for microbial inactivation purposes (Chang, 1989; Qin et al., 1994; Beveridge et al., 2002; Evrendilek and Zhang, 2005). 
This research aimed to assess the potential of the application of PEF, either as a stand-alone treatment or in a hurdle approach with moderate heating, for the intensification of the extraction of valuable compounds from wet $A$. platensis biomass using a continuous flow system. Specifically, the effect of field strength, energy input, pulse polarity, and inlet temperature of the algae biomass to the PEF chamber on the morphology of algae cells, as well as on the extractability of target intracellular compounds (e.g., water-soluble proteins, C-phycocyanin, and carbohydrates), was assessed.

\section{MATERIALS AND METHODS}

\section{Cultivation of Microalgae}

Biomass of $A$. platensis (PCC 8005) was kindly supplied by ATI Biotech Srl, an algae producer located in Castel Baronia (Avellino, Italy). A. platensis was cultivated in open pond systems, in which a maximum biomass concentration of about $0.4 \% \mathrm{DW}$ was achieved at the end of the exponential growth phase. After harvesting, the biomass was concentrated through a dewatering system consisting of vibrating screen filters, which allowed to increase the biomass concentration up to $12 \% \mathrm{DW}$. The microalgae paste was subsequently packed in polyethylene bags and immediately transported in an expanded polystyrene (EPS) box under refrigerated conditions to the laboratory of ProdAl S.c.a.r.l. (University of Salerno, Fisciano, Italy), where it was stored at $4^{\circ} \mathrm{C}$ until use, within 2 days from the delivery date.

Before processing, the algae paste was diluted with distilled water up to a final concentration $\left(C_{x}\right)$ of $2 \%$ DW with an initial conductivity of about $2.7 \mathrm{mS} / \mathrm{cm}$ at $25^{\circ} \mathrm{C}$ (Conductivitymeter HI 9033, Hanna Instrument, Milan, Italy). The biomass concentration was assessed using the method described by Goettel et al. (2013), with the pellet being dried in a circulating air-drying oven for $24 \mathrm{~h}$ at $80^{\circ} \mathrm{C}$.

\section{Pulsed Electric Fields System}

PEF experiments were conducted in a bench-scale continuous flow PEF system previously described in detail by Postma et al. (2016) and Carullo et al. (2018). Briefly, it consisted of a peristaltic pump used to transfer the microalgal suspension through a stainless steel coiled tube submerged into a water heating bath used to control the inlet temperature to the treatment chamber. The latter consisted of two modules, each made of two co-linear treatment chambers, hydraulically connected in series, with an inner radius of $1.5 \mathrm{~mm}$ and a gap distance of $4 \mathrm{~mm}$. The treatment chambers were connected to a high voltage pulsed power $(20 \mathrm{kV}-$ 100 A) generator (Diversified Technology Inc., Bedford, WA, United States) able to deliver either monopolar or bipolar square wave pulses at different pulse width $(1-10 \mu \mathrm{s})$, delay time between two consecutive pulses of opposite polarities (1-20 $\mu \mathrm{s})$ and pulse repetition rate $(1-1000 \mathrm{~Hz})$. The maximum electric field intensity $(\mathrm{E}$, in $\mathrm{kV} / \mathrm{cm})$ and total specific energy input $\left(\mathrm{W}_{\mathrm{T}}\right.$, in $\mathrm{kJ} / \mathrm{kg}_{\text {susp }}$ ) were measured and calculated as reported in Postma et al. (2016). T-thermocouples (Tersid S.r.L, Milan, Italy) were used to measure the product temperature at the inlet and outlet of each module of the PEF chamber. The total residence time of the algae suspension in the PEF plant at each processing temperature was about $25 \mathrm{~s}$.

\section{PEF Treatments}

PEF treatments were carried out by pumping algae suspension (2\% DW) from a feeding tank under stirring through the treatment chamber at a constant flow rate of $2 \mathrm{~L} / \mathrm{h}$. The operative pressure was about 1 bar. In all the experiments, the pulse width was fixed at $5 \mu \mathrm{s}$, while the electric field strength (E) and total specific energy input $\left(\mathrm{W}_{\mathrm{T}}\right)$ were set by varying the applied voltage and the pulse repetition frequency, respectively. The inlet biomass temperature $\left(\mathrm{T}_{\mathrm{IN}}\right)$ to the PEF treatment chamber was set at $25^{\circ} \mathrm{C}$ unless otherwise specified.

Three different experiments were carried out to investigate the effect of treatment intensity, pulse polarity, and inlet temperature on the cell damage and extraction efficiency of water-soluble compounds such as proteins, carbohydrates, and C-phycocyanins from A. platensis cells.

In the first set of experiments, a screening of the main electric parameters, namely field strength $(10,20$, and $30 \mathrm{kV} / \mathrm{cm})$ and energy input $\left(20,60\right.$, and $\left.100 \mathrm{~kJ} / \mathrm{kg}_{\text {susp }}\right)$, on the release of watersoluble compounds was investigated. The specific energy input per pulse $\left(\mathrm{W}_{\mathrm{p}}\right)$ was equal to $0.95,3.65$, and $8.36 \mathrm{~kJ} / \mathrm{kg}$, when the field strength was set at 10,20 , and $30 \mathrm{kV} / \mathrm{cm}$, respectively, and the number of pulses applied ranged between 2 and 105 . The results of this first set of experiments were used to define the optimal PEF conditions ( $\left.\mathrm{E}_{\mathrm{OPT}}, \mathrm{W}_{\mathrm{T}}, \mathrm{OPT}\right)$, which enabled the achievement of the highest recovery yields with the minimum treatment severity.

In the second set of experiments, a comparative study was carried out to investigate the effect of pulse polarity on the cell membrane permeabilization and extraction efficiency. Monopolar and bipolar pulses at different delay times $(1,5,10$, and $20 \mu \mathrm{s}$ ) were applied at the optimal field strength (EOPT) and energy input $\left(\mathrm{W}_{\mathrm{T}, \mathrm{OPT}}\right)$ defined during the first set of experiments. The typical voltage and current waveforms at the treatment chamber, for either monopolar or bipolar pulses at different delay times, are depicted in Figure 1.

Finally, the use of PEF treatments $\left(\mathrm{E}_{\mathrm{OPT}}, \mathrm{W}_{\mathrm{T}, \mathrm{OPT}}\right)$ applied using either monopolar or bipolar pulses in combination with mild heating treatment, achieved by raising the inlet biomass temperature $\left(\mathrm{T}_{\mathrm{IN}}\right)$ to the treatment chamber up to 25,35 , and $45^{\circ} \mathrm{C}$, was investigated to highlight the existence of possible synergistic effects of the combined treatment in the recovery process of intracellular compounds. Temperatures higher than $45^{\circ} \mathrm{C}$ were not tested in this work to prevent any damage to proteins as well as degradation of C-PC (Chaiklahan et al., 2012).

Under the selected operating conditions, the maximum temperature increase of the samples, detected at the exit of the treatment chamber, never exceeded $10^{\circ} \mathrm{C}$.

For the sake of comparison, untreated (control) samples of the same A. platensis suspension were pumped through the PEF plant with the heating bath set at 25,35 , or $45^{\circ} \mathrm{C}$, but with the PEF generator switched off.

At the exit of the treatment chamber, untreated (control) and PEF treated algae suspensions were immediately collected in plastic tubes and placed in an ice-water bath to be rapidly 


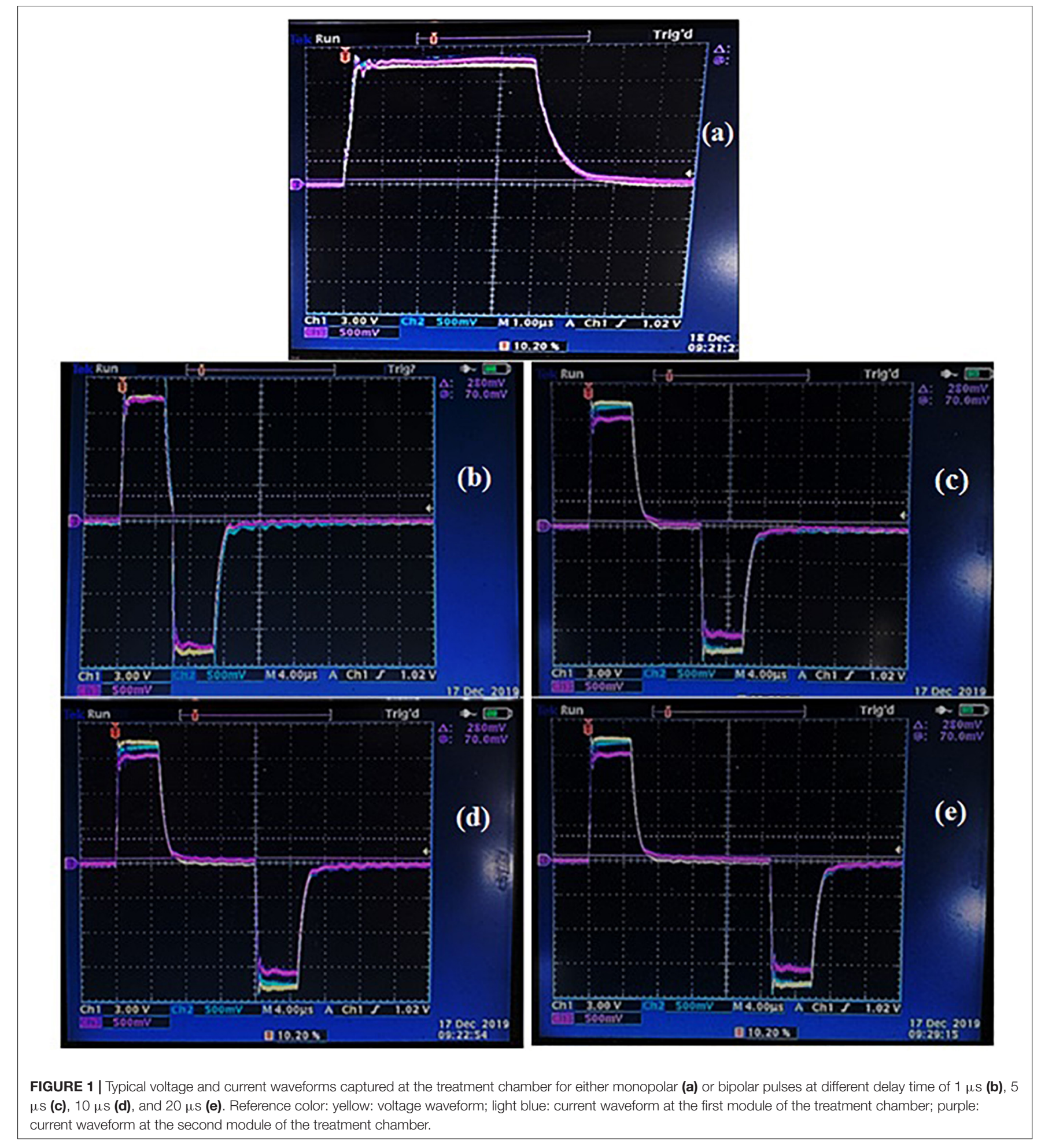

cooled up to a final temperature of $25^{\circ} \mathrm{C}$ before undergoing to the aqueous extraction process.

\section{Water Extraction}

Untreated and PEF treated samples of A. platensis suspensions were allowed to stand for $3 \mathrm{~h}$ at $25^{\circ} \mathrm{C}$ under gentle agitation
(160 rpm) in an orbital incubator (Model S150, PBI International, Milan, Italy) to allow intracellular components to diffuse out of the cells. Preliminary tests revealed that these conditions were sufficient to achieve significant extraction yields of the target intracellular compounds (data not shown). After this resting time, the cell suspensions were centrifuged for $10 \mathrm{~min}$ at $5700 \times \mathrm{g}$ 
(PK121R model, ALC International, Cologno Monzese, IT) in order to separate the spent pellets from the supernatants. The latter were then transferred to fresh tubes and stored at $-20^{\circ} \mathrm{C}$ until further analysis.

\section{Complete Cell Disruption by HPH Treatment}

$\mathrm{HPH}$ treatment was used to induce full disruption of $A$. platensis cells to enable the quantification of the total content of target intracellular compounds. HPH treatments were carried out by using an in-house developed laboratory scale high-pressure homogenizer (Carullo et al., 2018). The A. platensis suspensions, at the same concentration as for PEF treatment tests (2\% DW), were forced to pass through a $100 \mu \mathrm{m}$ diameter orifice valve (model WS1973, Maximator JET GmbH, Schweinfurt, Germany) upon pressurization through an air-driven Haskel pump (model DXHF-683, EGAR S.r.1., Milan, Italy). According to preliminary tests (data not shown), the full disruption of $A$. platensis cells and, hence, the complete release of intracellular compounds, was achieved at a pressure drop (P) across the orifice of $150 \mathrm{MPa}$ and after three homogenization passes $\left(n_{p}\right)$.

\section{Energy Analysis}

To enable the comparison in terms of energy efficiency among the different investigated extraction processes (i.e., PEF, mild heating, combination of $\mathrm{PEF}$ and mild heating, and $\mathrm{HPH}$ ), the energy consumed (EC) to extract $1 \mathrm{~kg}$ DW of target intracellular compounds, namely water-soluble proteins (WSP), C-phycocyanin (C-PC) and total carbohydrates $(\mathrm{CH})$, from A. platensis cell suspension, was calculated according to Eqs. $(1-3)$.

$$
\begin{aligned}
& E C_{P E F}=\frac{W_{T, O P T}}{C_{x} \cdot 3600 \cdot Y_{i}} \\
& E C_{H E A T I N G}=\frac{c_{P} \cdot\left(T_{I N}-T_{0}\right)}{C_{x} \cdot 3600 \cdot Y_{i}} \\
& E C_{H P H}=\frac{P \cdot n_{P}}{C_{x} \cdot \eta_{P U M P} \cdot 3600 \cdot \rho_{B I O M A S S} \cdot Y_{i}}
\end{aligned}
$$

where EC is expressed in $\mathrm{kWh} / \mathrm{kg}_{\mathrm{DW}}, C_{p}$ is the specific heat of the aqueous algae suspensions $(\sim 4.186 \mathrm{~kJ} / \mathrm{kg}), T_{0}$ is the reference temperature $\left(25^{\circ} \mathrm{C}\right), \eta_{P U M P}$ is the overall efficiency of $\mathrm{HPH}$ pumping system (0.87) (Carullo et al., 2018), $\rho_{\text {BIOMASS }}$ is the density of microalgal suspensions $\left(\sim 1000 \mathrm{~kg} / \mathrm{m}^{3}\right), 3600$ is the conversion factor between $\mathrm{kJ}$ and $\mathrm{kWh}$, and $Y_{i}$ is the recovery yield (in $\mathrm{kg} / \mathrm{kg}$ of $\mathrm{DW}$ microalgae) of the interest compounds ( $i=$ WSP, C-PC, CH) achieved upon the different extraction processes.

\section{Analytical Methods Optical Microscopy and Scanning Electron Microscopy (SEM) Analysis}

The morphological features and cellular details of untreated (control) and treated (PEF, HPH) algae cells were analyzed by using either optical or Scanning Electron Microscopy (SEM). In the first case, the microscopic images were acquired with an inverted optical microscope (Nikon Eclipse TE2000-S) at $20 \times$ magnification. For SEM analysis, pellets derived from the centrifugation of untreated and treated (PEF or $\mathrm{HPH}$ ) algae suspensions were prepared as described by Carullo et al. (2018) and analyzed in a high-resolution ZEISS HD15 Scanning Electron Microscope (Zeiss, Oberkochen, Germany).

\section{Proteins Analysis}

The water-soluble proteins content of supernatants from untreated, PEF, and HPH treated samples was evaluated by using the method of Lowry et al. (1951), with some modifications as described elsewhere (Carullo et al., 2018). Specifically, the reactive system consisted in $0.5 \mathrm{~mL}$ of diluted $(1 / 2, \mathrm{v} / \mathrm{v}$ in ultrapure water) Folin-Ciocalteau reactive (Folin and Ciocalteau, 1927), to which $1 \mathrm{~mL}$ of fresh sample (supernatant), previously mixed with $5.0 \mathrm{~mL}$ of the reactive " $\mathrm{C}$ " [50 volumes of reactive "A" $\left(2 \% \mathrm{Na}_{2} \mathrm{CO}_{3}+0.1 \mathrm{~N} \mathrm{NaOH}\right)+1$ volume of reactive "B" (1/2 volume of $0.5 \% \cdot \mathrm{CuSO}_{4} 5 \mathrm{H}_{2} \mathrm{O}+1 / 2$ volume of $1 \% \mathrm{KNaC}_{4} \mathrm{H}_{4} \mathrm{O}_{6} \cdot 4 \mathrm{H}_{2} \mathrm{O}$ )] (Sigma Aldrich, Milan, Italy) were added. Absorbance was measured at $750 \mathrm{~nm}$ against a blank (5 $\mathrm{mL}$ reactive " $\mathrm{C}$ " $+1 \mathrm{~mL}$ deionized water $+0.5 \mathrm{~mL}$ FolinCiocalteau reactants), $35 \mathrm{~min}$ after the start of the chemical reaction, by using a V-650 Spectrophotometer (Jasco Inc., Easton, MD, United States). Bovine serum albumin (BSA) (A7030, Sigma Aldrich, Milan, Italy) was used as a protein standard. The protein yield ( $\mathrm{Y}_{\mathrm{WSP}}$ ) was expressed as:

$$
Y_{W S P}=\frac{C_{W S P, \text { sup }}}{C_{W S P, \text { biomass }}}
$$

where $\mathrm{C}_{W S P}$,sup is the protein content in the supernatant (\% $\mathrm{DW}$ ), and $\mathrm{C}_{\mathrm{WSP} \text {, biomass }}$ is the total protein content on DW (\% DW) achieved upon HPH treatment.

\section{Carbohydrates Analysis}

The total carbohydrates concentration of the supernatants was analyzed according to the phenol-sulfuric acid method previously described by DuBois et al. (1956). $0.2 \mathrm{~mL}$ of $5 \%$ (w/w) phenol and $1 \mathrm{~mL}$ of concentrated sulfuric acid (Sigma Aldrich, St. Louis, United States) were added to $0.2 \mathrm{~mL}$ of diluted supernatant (Dilution Factor $=5$ ). Samples were then incubated at $35^{\circ} \mathrm{C}$ for $30 \mathrm{~min}$ before reading the absorbance at $490 \mathrm{~nm}$ against a blank of $0.2 \mathrm{~mL} \mathrm{5 \%}(\mathrm{w} / \mathrm{w})$ phenol, $1 \mathrm{~mL}$ concentrated sulfuric acid, and $0.2 \mathrm{~mL}$ of deionized water. D-Glucose (G8270, Sigma-Aldrich, Milan, Italy) was used as a standard. The carbohydrate yield $\left(\mathrm{Y}_{\mathrm{CH}}\right)$ was expressed as:

$$
Y_{C H}=\frac{C_{C H, \text { sup }}}{C_{C H, \text { biomass }}}
$$

where $\mathrm{C}_{\mathrm{CH} \text {,sup }}$ is the carbohydrates content in the supernatant (\% DW) and $\mathrm{C}_{\mathrm{CH} \text {,biomass }}$ is the total carbohydrates content on DW (\% DW) achieved upon HPH treatment.

\section{C-Phycocyanin (C-PC) and Purity Ratio}

The quantification of C-PC content of the supernatants was performed according to the method of Bennett and Bogorad (1973), which is based on the measurements of absorbance 
(A) of the samples at two fixed wavelengths $\left(\lambda_{1}=615 \mathrm{~nm}\right.$, and $\lambda_{2}=652 \mathrm{~nm}$ ). The C-phycocyanin concentration (C-PC), expressed as $\mathrm{mg} / \mathrm{g}_{\mathrm{DW}}$ of supernatant, was evaluated according to Eq. (6):

$$
C-P C=\frac{\left(A_{615 n m}-0.474 \cdot A_{652 n m}\right)}{5.34 \cdot C_{x}}
$$

The C-PC yield $\left(\mathrm{Y}_{C-P C}\right)$ was expressed as:

$$
Y_{C-P C}=\frac{C_{C-P C, \text { sup }}}{C_{C-P C, \text { biomass }}}
$$

where $\mathrm{C}_{\mathrm{C}-\mathrm{PC} \text {,sup }}$ is the $\mathrm{C}-\mathrm{PC}$ content in the supernatant (\% DW),

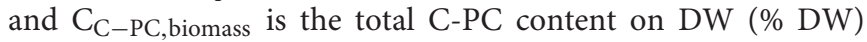
achieved upon $\mathrm{HPH}$ treatment.

The purity of C-PC extract was monitored spectrophotometrically and calculated by the Eq. (8) (Abelde et al., 1998; Martinez et al., 2017):

$$
E P=\frac{A_{615 n m}}{A_{280 n m}}
$$

where EP is the protein extract purity, $\mathrm{A}_{615} \mathrm{~nm}$ absorbance represents the maximum absorption of the C-phycocyanin peak, proportional to its concentration in the supernatant, and $\mathrm{A}_{280}$ $\mathrm{nm}$ is the absorbance of the at $280 \mathrm{~nm}$, indicating the total concentration of proteins in the supernatant.

\section{Statistical Analysis}

All treatments and analyses were performed in triplicate and the results were reported as mean values \pm standard deviations. The statistical analysis was performed with IBM SPSS Statistics 20.0 (SPSS Inc., Chicago, United States) software by means of Oneway analysis of variance (ANOVA). Tukey's test was executed at a fixed significance level ( $p \leq 0.05)$, for the determination of any statistical difference among the untreated and processed samples.

\section{RESULTS AND DISCUSSION}

\section{Influence of PEF Treatment Intensity on the Recovery of Water-Soluble Intracellular Compounds}

The biomass composition of $A$. platensis used in this study was quantified upon complete cell disruption by $\mathrm{HPH}$ treatment $\left(P=150 \mathrm{MPa} ; n_{P}=3\right)$. Results revealed that the extractable content of WSP and $\mathrm{CH}$ from A. platensis cells was $68.5 \%$ DW and $15.8 \%$ DW, respectively, which are in line with the total content of proteins (55-70\% DW) and carbohydrates (13$20 \%$ DW) typically reported for this cyanobacterium (Lupatini et al., 2016). At the same time, it was also found that the total content of C-PC was $5.7 \% \mathrm{DW}$, which is consistent with the content found in other works (Martinez et al., 2017; Jaeschke et al., 2019). The results of this study will be presented in terms of extraction yields expressed with respect to this biomass composition according to Eqs. (4-6).

Figure 2 shows the extraction yields of water-soluble proteins (WSP) and carbohydrates $(\mathrm{CH})$ detected in the supernatant of untreated and PEF-treated (monopolar pulses; $\mathrm{T}_{\mathrm{IN}}=25^{\circ} \mathrm{C}$ ) A. platensis cell suspensions at different field strength (10$30 \mathrm{kV} / \mathrm{cm})$ and energy input $\left(20-100 \mathrm{~kJ} / \mathrm{kg}_{\text {susp }}\right)$, after $3 \mathrm{~h}$ of extraction in water.

Results show that a small leakage of water-soluble compounds from untreated algae cells occurred during the extraction step, leading to final yields of proteins and carbohydrates in the aqueous supernatant of 2.2 and $14.8 \%$, respectively. This leakage of intracellular compounds may be ascribed to either a concentration gradient across the intact cell membranes or to spontaneous cell lysis (Carullo et al., 2018).

The exposure of $A$. platensis cell suspensions to an external electric field that caused the electroporation of cytoplasmatic membranes, thus facilitating the mass transfer of intracellular compounds toward the external medium, markedly enhanced the extraction efficiency up to 12.7-fold for WSP and 4.6fold for $\mathrm{CH}$, as compared with untreated samples. However, significant differences $(p \leq 0.05)$ between untreated and PEFtreated samples were detected only when energy input greater than $20 \mathrm{~kJ} / \mathrm{kg}_{\text {susp }}$ were delivered to the algae suspension, independently of the field strength applied. This observation confirms the results obtained by other scientists on the electroporation of bacteria and microalgae (Garcia et al., 2007; Luengo et al., 2015; Martinez et al., 2017; Carullo et al., 2018; Jaeschke et al., 2019), indicating the key role played by the energy input, besides the electric field strength applied, in determining the degree of cell membrane permeabilization required to intensify the extractability of target intracellular compounds.

Moreover, it is worth noting that, among the PEF-treated samples, the applied field strength was likely high enough to induce the electroporation of the algae cells so that its effect appeared less important than that of the energy input within the investigated range, which is in agreement with previous findings (Pataro et al., 2017, 2019; 't Lam et al., 2017a; Carullo et al., 2018). In particular, significant differences $(p \leq 0.05)$ in the content of both intracellular compounds were detected when PEF treatments were carried out at different energy inputs, regardless of the field strength applied. As an example, when the energy input was increased from 60 to $100 \mathrm{~kJ} / \mathrm{kg}_{\text {susp }}$ at $20 \mathrm{kV} / \mathrm{cm}$, the content of proteins and carbohydrates in the supernatant increased by 2.7 and 2.2 times, respectively. In contrast, when PEF treatments were carried out at different field strengths, significant $(p \leq 0.05)$ increase in the content of both proteins and carbohydrates was detected only when the field strength was increased from 10 to $20 \mathrm{kV} / \mathrm{cm}$ and for a fixed energy input of

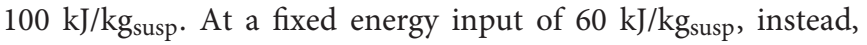
a significant $(p \leq 0.05)$ increase was observed only for proteins when the field strength was increased from 10 to $30 \mathrm{kV} / \mathrm{cm}$.

From the results of Figure 2, it can be concluded that a field strength of $20 \mathrm{kV} / \mathrm{cm}$ and an energy input of $100 \mathrm{~kJ} / \mathrm{kg}_{\text {susp }}$ were sufficient to significantly intensify the extractability of proteins and carbohydrates from $A$. platensis cells, leading to extraction yields of 25.4 and $64.1 \%$ of biomass WSP and $\mathrm{CH}$ content, respectively.

The positive impact of PEF pre-treatment on the extraction of valuable intracellular compounds from A. platensis cell suspensions was also previously observed by other scientists 

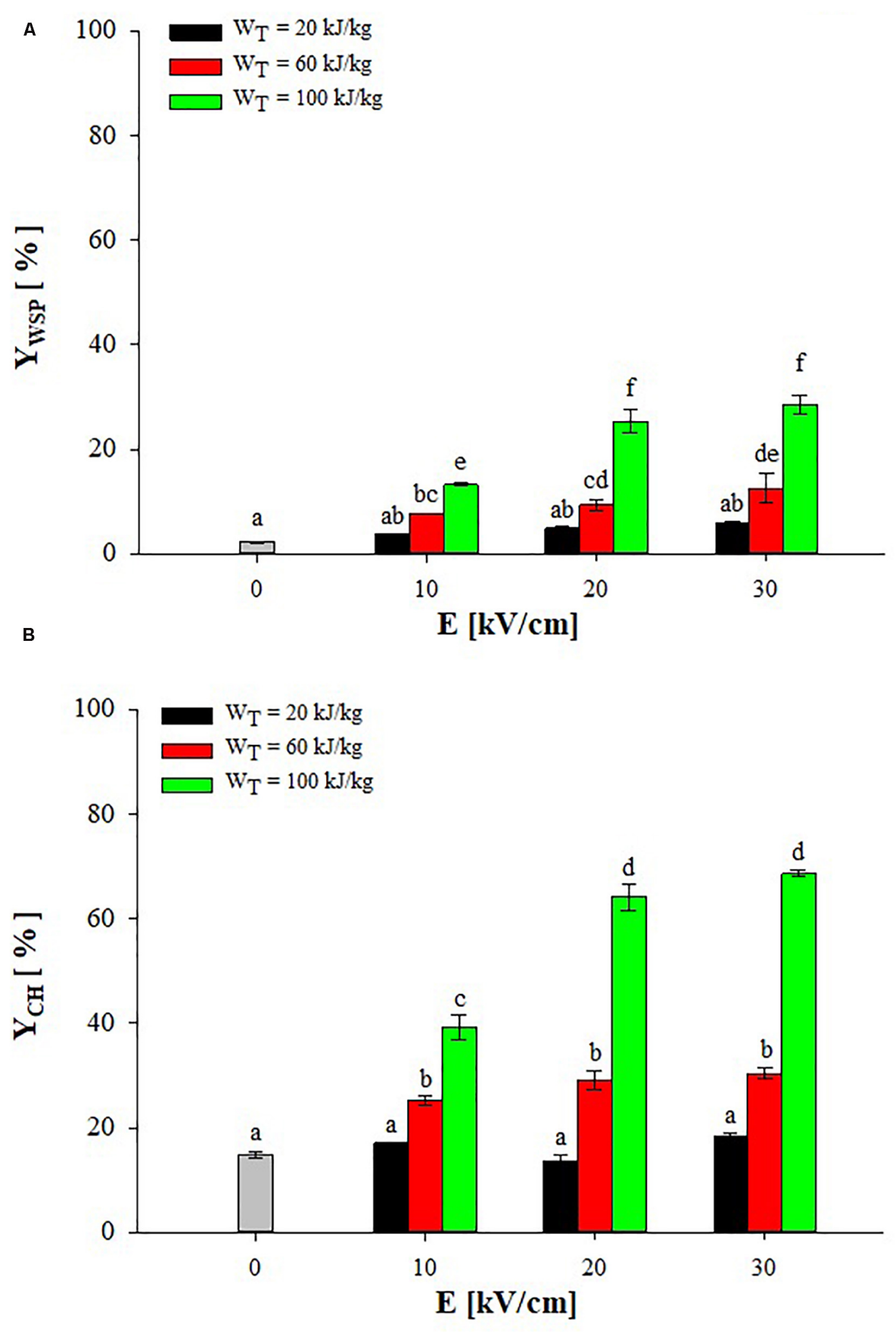

FIGURE 2 | Extraction yield of water-soluble proteins (A) and carbohydrates $(\mathbf{B})$ in the supernatant of untreated $(0 \mathrm{kV} / \mathrm{cm})$ and $\mathrm{PEF}\left(\mathrm{T}_{\mathrm{IN}}=25^{\circ} \mathrm{C}\right)$ treated $A . p l a t e n s i s$ suspension $3 \mathrm{~h}$ after treatment as a function of the field strength and for different energy input. The yields were calculated considering $100 \%$ extraction yield upon the $\mathrm{HPH}$ treatment $\left(P=150 \mathrm{MPa}, n_{P}=3\right)$. Different letters above the bars indicate significant differences among the mean values of the samples $(p \leq 0.05)$. 
(Aouir et al., 2015; Martinez et al., 2017; Jaeschke et al., 2019), even though, to date, only Jaeschke et al. (2019) focused on PEFassisted extraction of total proteins, while no work was addressed to the extractability of carbohydrates from this cyanobacteria. However, these authors found a lower amount in WSP $(4.84 \%$ DW biomass) as compared with that detected in the present work (17.4\% DW biomass), despite the algae suspension was subjected to similar energy input (56-122 kJ/ $\mathrm{kg}_{\text {susp }}$ ) but at higher field strength $(40 \mathrm{kV} / \mathrm{cm})$ than those used in our work. The differences in PEF equipment, experimental conditions, algae strain, and cultivation techniques could contribute to explain these different results.

Moreover, in agreement with previous research (Goettel et al., 2013; Postma et al., 2016; Pataro et al., 2017; 't Lam et al., 2017a; Carullo et al., 2018), results of the present work seem to highlight the capacity of PEF to efficiently release small components, such as $\mathrm{CH}$ and WSP of small molecular weight, while most proteins, which are likely larger and more bounded to intracellular structure, remained entrapped into cells after PEF treatment. This may be explained considering that, in comparison with $\mathrm{HPH}, \mathrm{PEF}$ is a mild disruption technology able to simply permeabilize the cell membranes (Carullo et al., 2018), without affecting the rigid outer cell wall of most algae cells ('t Lam et al., 2017b), thus limiting the mass transfer of some intracellular compounds.

In this line, differences in cell wall composition could in part also explain the higher extraction yields of protein $(17.1 \% \mathrm{DW})$ achieved in this work after aqueous extraction of PEF-treated A. platensis cells (Figure 2), in comparison to those (1-13\% DW) detected by other scientists for different microalgae species, such as Chlorella vulgaris, Auxenochlorella protothecoides, Neochloris oleoabundans, C. reinhardtii (Goettel et al., 2013; Postma et al., 2016; Pataro et al., 2017; 't Lam et al., 2017a,b; Carullo et al., 2018). It is known that $A$. platensis has a relatively fragile cell wall, composed mainly of murein (peptidoglycan) without any cellulose (Lu et al., 2006; Safi et al., 2014), while the other microalgae cited above have a more robust cell wall, mainly composed of cellulose and hemicelluloses, which would explain the lower protein extraction yield in these cases (Lu et al., 2006; Safi et al., 2015; Jaeschke et al., 2019).

According to the results shown so far, further investigations aimed at studying the influence of pulse polarity and mild heating on the extraction efficiency of valuable compounds from A. platensis cell suspensions were carried out with the PEF conditions set at $20 \mathrm{kV} / \mathrm{cm}$ and $100 \mathrm{~kJ} / \mathrm{kg}_{\text {susp }}$.

\section{Effect of Pulse Polarity on the Recovery of Water-Soluble Compounds and Cell Morphology}

Figure 3 shows the extraction yields of WSP and $\mathrm{CH}$ detected in aqueous extracts obtained from untreated and PEF treated A. platensis cell suspensions at constant treatment intensity $\left(\mathrm{E}=20 \mathrm{kV} / \mathrm{cm} ; \mathrm{W}_{\mathrm{T}}=100 \mathrm{~kJ} / \mathrm{kg}_{\text {susp }}\right)$ and inlet temperature $\left(\mathrm{T}_{\mathrm{IN}}=25^{\circ} \mathrm{C}\right)$, using either monopolar pulses or bipolar pulses at variable delay times $(1-20 \mu \mathrm{s})$. The results show that, regardless of the delay time, bipolar pulses significantly $(p \leq 0.05)$ increased
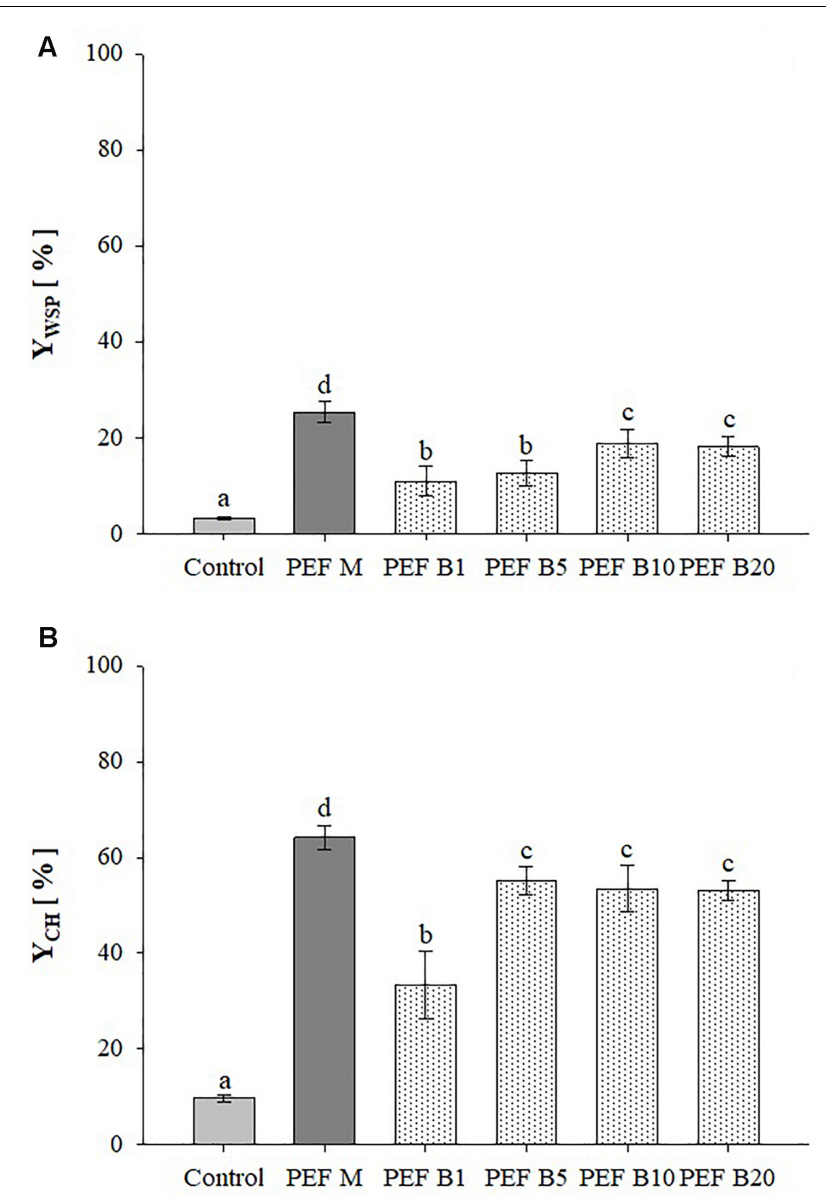

FIGURE 3 | Extraction yield of water-soluble proteins (A) and carbohydrates (B) in the supernatant of untreated (Control) and PEF-treated ( $E=20 \mathrm{kV} / \mathrm{cm}$; $W_{\mathrm{T}}=100 \mathrm{~kJ} / \mathrm{kg}_{\text {susp }} ; \mathrm{T}_{\mathrm{IN}}=25^{\circ} \mathrm{C}$ ) A. platensis suspensions with either monopolar (M) or bipolar (B) pulses at variable delay time (1, 5, 10, and 20 $\mu \mathrm{s})$. The yields were calculated considering $100 \%$ extraction yield upon the $\mathrm{HPH}$ treatment $\left(P=150 \mathrm{MPa}, n_{P}=3\right)$. Different letters above the bars indicate significant differences among the mean values $(p \leq 0.05)$.

the content of WSP and $\mathrm{CH}$ in the extracts, as compared with untreated samples. Interestingly, changing in pulse delaying times resulted in different extraction yields of the intracellular compounds of interest, showing the existence of a threshold delay time above which no additional positive effect was detected. In particular, significant differences $(p \leq 0.05)$ were observed only when the delay time was increased from 5 to $10 \mu \mathrm{s}$ for proteins and from 1 to $5 \mu \mathrm{s}$ for carbohydrates, which led to a maximum recovery yield of 18.8 and $55.2 \%$, respectively.

To the best of our knowledge, the literature data lack sufficient information on the effect of bipolar pulses at different delay times on the extractability of valuable intracellular compounds from algae cells. However, when looking into microbial inactivation, Evrendilek and Zhang (2005) reported that changing pulse delaying times within the range 3-1430 $\mu$ s resulted in different inactivation levels of E. coli O157:H7 inoculated in either apple juice or skim milk. In particular, the authors found that $20 \mu \mathrm{s}$ 
was the most effective delay-time value within the investigated range, which appears somehow consistent with results achieved in the present study. The authors concluded that most probably, there was not enough time to charge capacitors of their pulse generator after each discharging when the duration of pulse delay time was really short $(3-5 \mu \mathrm{s})$. On the other hand, as the delay time between pulses of opposite polarities was lengthened up to $1430 \mu \mathrm{s}$, the time interval between two pulses of opposite polarity was so long that adversely affected the efficacy of the treatment. This explanation could not justify our results due to the narrower range of delay time investigated and to the fact that the same voltage value was measured across the electrodes of the treatment chamber when bipolar pulses of different delaying times were delivered (data not shown).

As it is shown in Figure 3, the extracts obtained for the application of bipolar pulses showed significantly $(p \leq 0.05)$ lower yields of intracellular compounds of interest, as compared to the samples treated with monopolar pulses, being the extraction efficiency decreased by 1.4 -fold for proteins and 1.2fold for carbohydrates.

Only a few authors have investigated the comparative effect of mono ad bipolar pulses on the extent of cell membrane permeabilization of biological cells, but focusing only on microbial inactivation and obtaining controversial results. For example, Chang (1989) and Qin et al. (1994) found that bipolar pulses provided a more efficient inactivation of microorganisms in liquid foods, as compared to monopolar pulses. To explain these results the authors proposed that the alternating stress induced by bipolar pulses results in structural fatigue of the membrane, which thereby enhances its susceptibility to electrical breakdown. In contrast with these findings, Beveridge et al. (2002) observed that bipolar pulses did not provide superior inactivation levels of different bacterial cells compared with monopolar pulses. In another study, Evrendilek and Zhang (2005) found that there was no significant difference $(p>0.05)$ between mono and bipolar pulses on the inactivation of bacterial cells inoculated into apple juice, while bipolar pulses resulted significantly more efficient than their monopolar counterpart for the inactivation of the same bacteria in skim milk. In agreement with Qin et al. (1994), the authors explained this different behavior as due to the deposition of milk proteins on the electrode surface (fouling effect) when monopolar pulses were applied, which caused several problems such as distortion of the electric field within the treatment zone, thus lowering the PEF performance.

In the case of the results of Figure 3, the lower extractability of water-soluble molecules from $A$. platensis cells measured for bipolar pulses than for monopolar ones applied at the same intensity could be explained in term of the slightly lower efficacy in opening the pores at the cellular membrane level of the bipolar pulses. In particular, this explanation can be supported by the previously observed polarization behavior of the cell membranes when exposed to pulses of different polarity and delay time (Beveridge et al., 2002). In this regard, it can be hypothesized that when monopolar pulses of sufficient width and amplitude, such as those used in this work, are applied, a cumulative buildup of charges across the cell membrane occurs, and when the transmembrane potential threshold is exceeded, the membrane becomes electroporated, exhibiting increased permeability. On the other hand, when polarities switch in the bipolar pulses, an effect of residual polarization, due to the so-called cancelation or healing mechanism (Beveridge et al., 2002; Sweeney et al., 2016), may occur that would decrease the probability of membrane permeabilization. In such a case, it has been proposed that the polarization effect induced by the previous pulse would first have to be neutralized before reverse polarization of the membrane can occur when the second pulse of opposite polarity is applied. This effect could cause an incomplete charging of cell membranes, leading to the formation of a smaller number of pores or pores of smaller size in the cell membrane than those induced by monopolar pulses of the same intensity, lowering the extractability of intracellular compounds. However, such cancelation effect could be partially mitigated at the expense of either higher applied voltages or by increasing the time elapsing between two consecutive pulses of opposite polarity (Sweeney et al., 2016), as if they were delivered independently, which is consistent with results presented in Figure 3.

The results of Figure 3 are also corroborated by the micrographs presented in Figure 4, which clearly show the different impact of $\mathrm{HPH}$ treatments and PEF treatments of different pulse polarity on the morphology of A. platensis cells. From the micrographs of Figure $4 \mathrm{~A}$ it is possible to notice that, as expected, HPH caused the complete disruption of A. platensis cells and the formation of cell debris, which was consistent with the results of Figure 3. The application of a PEF treatment with monopolar pulses (PEF M) caused only the partial separation of trichomes that form the characteristic cylindrical filaments of A. platensis, and preserved the overall structure of the cells, avoiding the formation of cells debris. It is also worth noting that PEF M treatment induced the formation of colored spots surrounding the algae cells (red arrows), likely due to the leakage of intracellular matter into the extraction medium, which can be attributed to the formation of pores in the cell membranes of the algae cells. Similarly, Martinez et al. (2017) observed that, while a highly intensive cell disruption method, such as bead milling, caused the complete breakage of the A. platensis cells, PEF treatments carried out using monopolar pulses led only to a partial fragmentation of cells in trichomes, with no visible effects on the whole structure of the algae, but with a clear release of intracellular matter.

In contrast, the application of bipolar pulses (PEF B) evidenced a lower release of intracellular matters and a lower separation of cells in trichomes than monopolar pulses, thus revealing a lower capability of inducing electroporation phenomena, which is consistent with the results illustrated in Figure 3.

The results of Figure $\mathbf{4 A}$ are also supported by the corresponding SEM images shown in Figure 4B. The surface of untreated $A$. platensis cells appeared regular and smooth. Interestingly, the application of PEF with either monopolar (PEF $\mathrm{M}$ ) or bipolar (PEF B) pulses led to an increase of surface roughness and the formation of cracks and depressions on the surface of the cells, more evident for the samples treated with monopolar pulses, which could be ascribed to the mentioned 


\section{A}

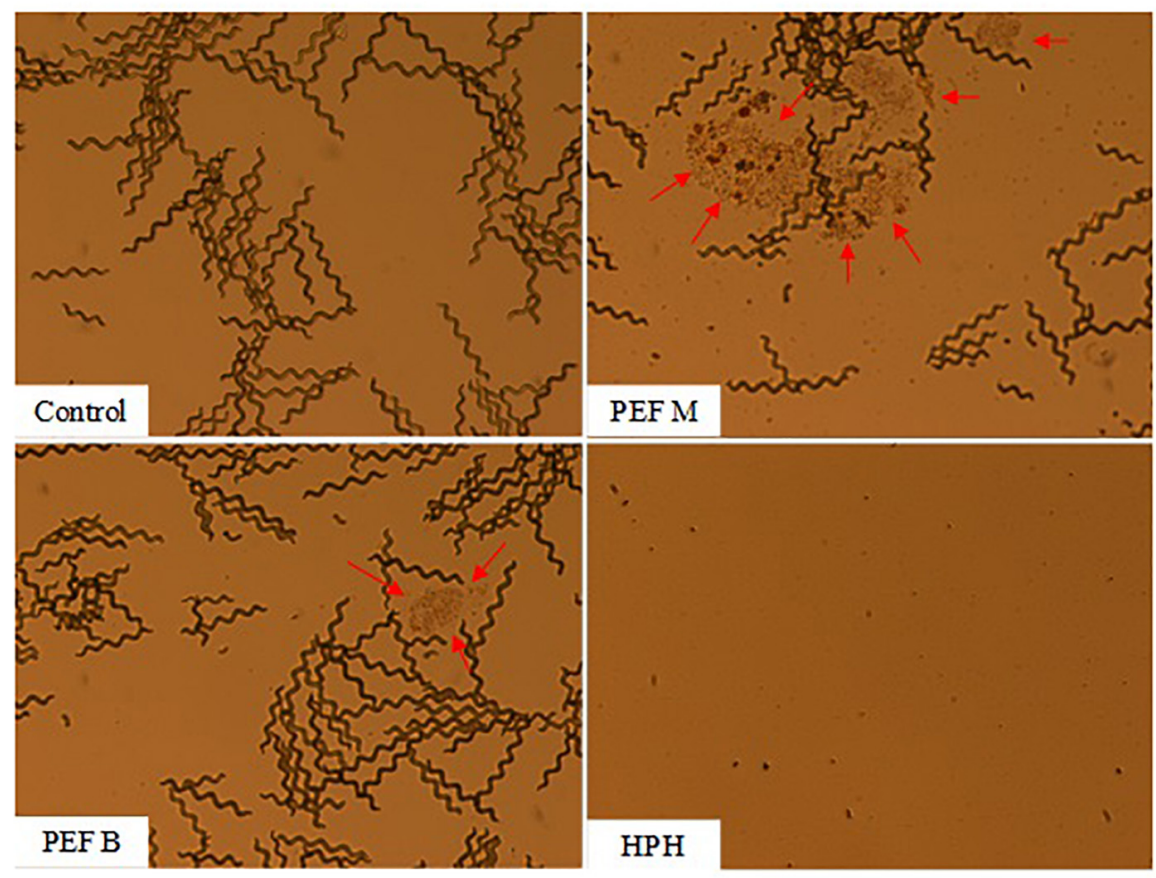

$\mathbf{B}$

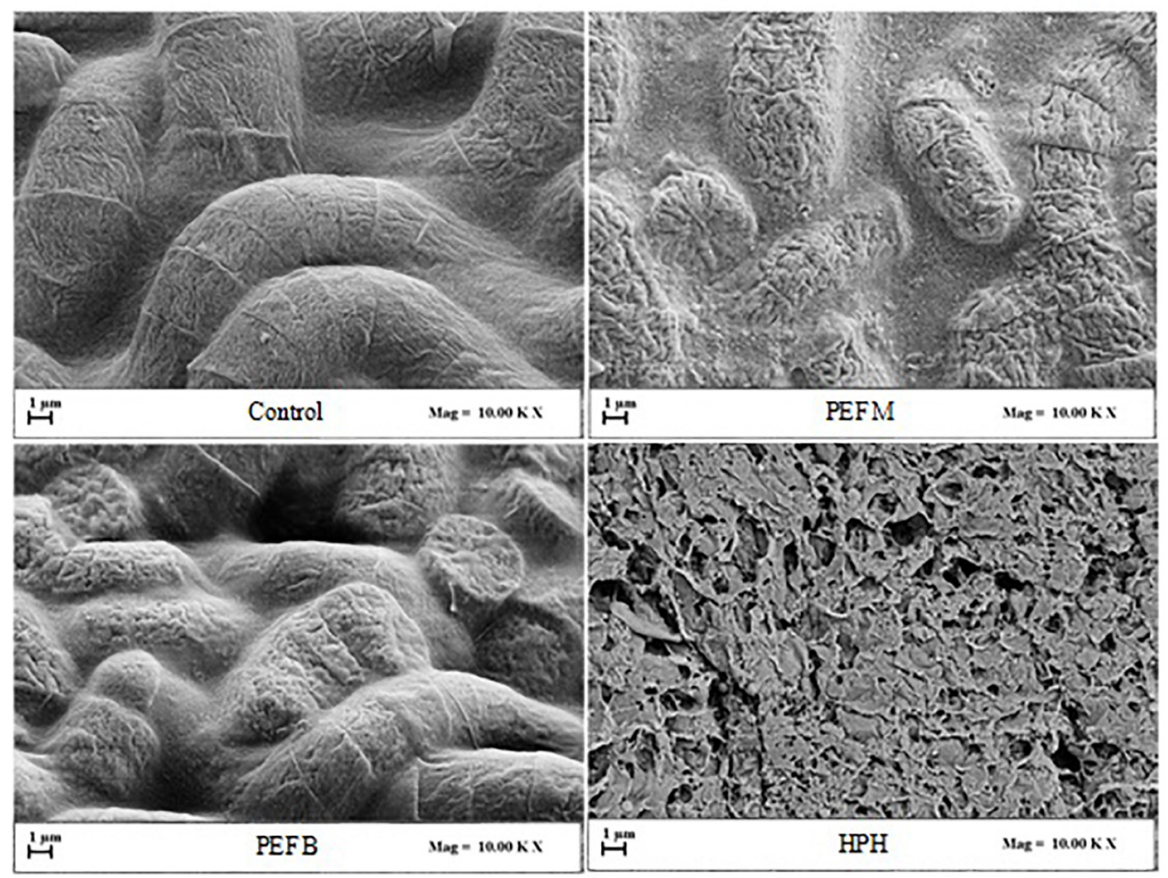

FIGURE 4 | Optical microscopy (20x magnification) (A) and scanning electron microscopy (SEM) (B) of $A$. platensis cells, before (Control) and after PEF $\left(E=20 \mathrm{kV} / \mathrm{cm} ; W_{\mathrm{T}}=100 \mathrm{~kJ} / \mathrm{kg}_{\text {susp }} ; \mathrm{T}_{\mathbb{N}}=25^{\circ} \mathrm{C}\right)$ using either monopolar (PEF M) or bipolar (PEF B) pulses, and HPH $\left(P=150 \mathrm{MPa} ; n_{P}=3\right)$ treatment. Red arrows indicate release of intracellular material.

more intense electroporation phenomena and subsequent more abundant leakage of intracellular compounds. Similar findings were previously reported by Han et al. (2019), who observed an increase in surface roughness of C. pyrenoidosa cells after the electroporation effect induced upon the application of PEF treatment at $20 \mathrm{kV} / \mathrm{cm}$. On the other hand, in agreement with 
the results of a previous research carried out on C. vulgaris microalgae (Carullo et al., 2018), the results of Figure 4B show that HPH treatment led to the formation of a large amount of cell debris, reflecting its capability of inducing full cell disruption (Figure 2).

\section{Effect of Combined PEF-Temperature Treatment on the Extractability of Water-Soluble Compounds}

Processing temperature during PEF treatment, through the interaction with the electrical parameters, may influence the extent of membrane electroporation and the subsequent extraction of intracellular compounds from PEF-treated biomass. Therefore, the potential of PEF in a hurdle approach with mild heating was investigated to furtherly intensify the recovery yield of water-soluble compounds.

Figure 5 shows the extraction yields of WSP, CH, and C-PC as well as the C-PC purity for untreated and PEF-treated $\left(E=20 \mathrm{kV} / \mathrm{cm}, W_{T}=100 \mathrm{~kJ} / \mathrm{kg}_{\text {susp }}\right)$ A. platensis cell suspensions, using either monopolar and bipolar pulses, after mildly preheating the algae biomass at temperatures from 25 to $45^{\circ} \mathrm{C}$.
The results show that only a small fraction of the total content of WSP ( $\left.\mathrm{Y}_{\mathrm{WSP}}<1.1 \%\right), \mathrm{CH}\left(\mathrm{Y}_{\mathrm{CH}}<5.2 \%\right)$, and $\mathrm{C}-\mathrm{PC}\left(\mathrm{Y}_{\mathrm{C}-\mathrm{PC}}<2.5 \%\right)$ was released in the supernatant of the algae suspensions at a processing temperature between 25 and $45^{\circ} \mathrm{C}$ when no PEF treatment was applied. This suggests that no cell structural damage was induced by either pumping of A. platensis cell suspensions through the PEF plant or by mild heating. This is also corroborated by the findings of Jaeschke et al. (2019), who observed that pumping alone or thermal treatment at $42^{\circ} \mathrm{C}$ for $15 \mathrm{~min}$ of A. platensis cell suspensions were not sufficient to induce damages in the cell envelope and to extract appreciable amounts of WSP and C-PC, even after $6 \mathrm{~h}$ of incubation.

However, when PEF pre-treatments of different polarity were applied at processing temperature between 25 and $45^{\circ} \mathrm{C}$, the amount of WSP (Figure 5A), CH (Figure 5B), and C-PC (Figure 5C) significantly $(p \leq 0.05)$ increased, as compared with untreated samples, in a manner dependent on pulse polarity, temperature and type of compounds to be extracted. In particular, the capability of PEF treatment at room temperature to induce cell membrane permeabilization, and the subsequent intensification of the extractability of WSP $(25.4 \%$ for PEF
A

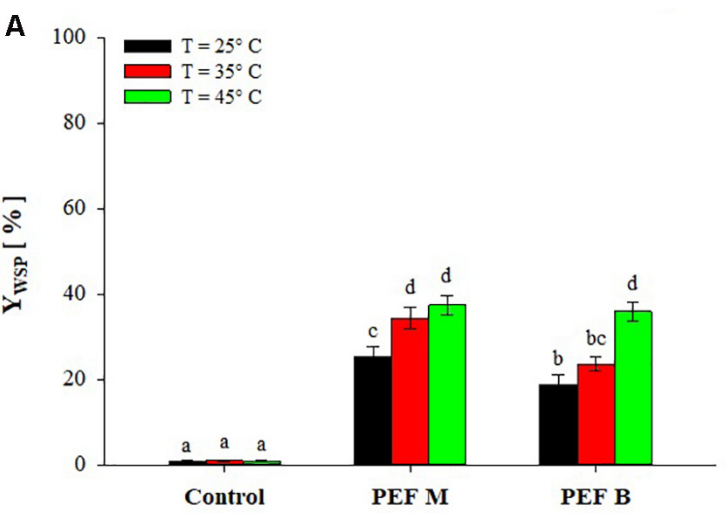

B

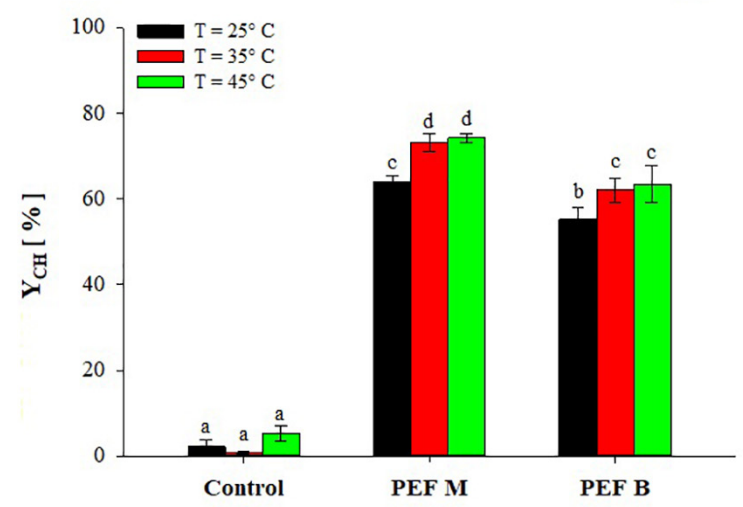

C

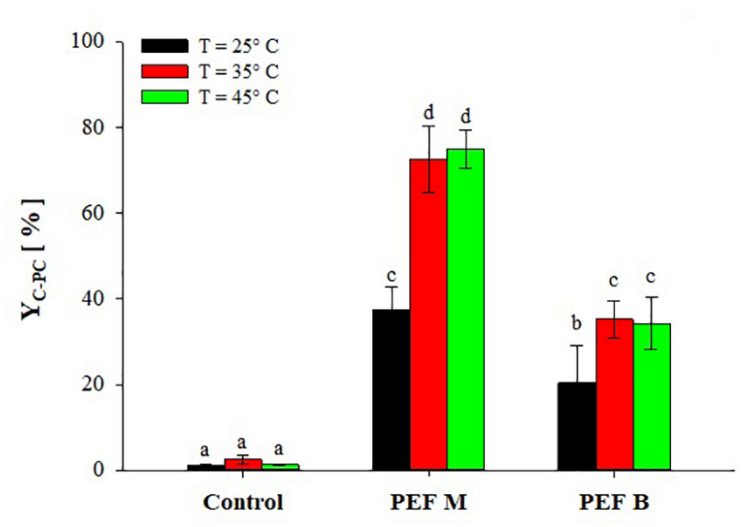

D

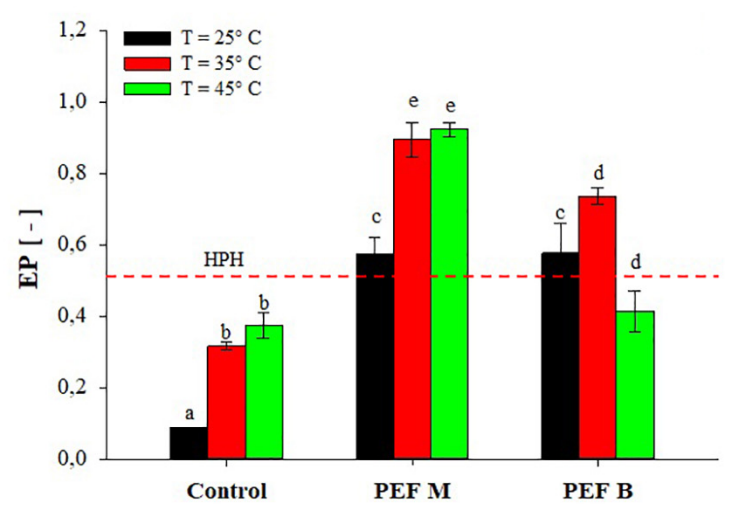

FIGURE 5 | Extraction yield of water-soluble proteins (A), carbohydrates (B), and C-PC (C), and protein purity (D) of extracts obtained from untreated (Control) and PEF-treated $\left(E=20 \mathrm{kV} / \mathrm{cm} ; W_{T}=100 \mathrm{~kJ} / \mathrm{kg}_{\text {susp }}\right) A$. platensis suspensions with either monopolar (M) or bipolar (B) pulses (10 $\mu$ s pulse delay time), as a function of the inlet processing temperature The yields were calculated considering $100 \%$ extraction yield upon the HPH treatment $\left(P=150 \mathrm{MPa}, n_{P}=3\right)$. Different letters above the bars indicate significant differences among the mean values $(p \leq 0.05)$. 
$\mathrm{M}, 18.8 \%$ for $\mathrm{PEF} \mathrm{B})$ and $\mathrm{CH}(64.1 \%$ for $\mathrm{PEF} \mathrm{M}, 55.2 \%$ for PEF B), has been also previously shown in Figures 2, 3. Coherently with these findings, the results of Figure 5C show that the application of PEF treatment at room temperature also caused a significant $(p \leq 0.05)$ improvement in the release of C-PC, as compared with the untreated samples, leading to an extraction yield of $37.4 \%$ for monopolar pulses and $20.4 \%$ for bipolar pulses.

However, when the processing temperature was raised to $35^{\circ} \mathrm{C}$, a clear synergistic effect of the combined treatment was detected for monopolar pulses, leading to an increase in WSP, $\mathrm{CH}$, and $\mathrm{C}-\mathrm{PC}$ yields up to $34.4,73.1$, and $72.5 \%$, respectively. At this processing temperature, a slight synergistic effect was also observed when bipolar pulses were applied which, however, still appeared less effective than monopolar pulses, leading to extraction yields of $23.7,62.0$, and $35.2 \%$ for WSP, $\mathrm{CH}$, and C-PC, respectively.

Further increases of the processing temperature up to $45^{\circ} \mathrm{C}$ appeared to contribute to a significant $(p \leq 0.05)$ increase in the extraction yield, but only for WSP and when bipolar pulses were applied. It is worth noting that, in this latter case, the extraction yield of WSP increased up to $36.0 \%$, a level comparable to that detected in samples treated with monopolar pulses $(37.4 \%)$ at the same temperature.

The observed increase in the release of intracellular compounds with increasing of the inlet processing temperature up to $45^{\circ} \mathrm{C}$ during $\mathrm{PEF}$ treatment, was likely due to the interaction between field strength and temperature rather than further cellular damages induced by excessive heating of the samples. This is corroborated by the fact that the maximum sample temperature measured at the exit of the PEF chamber was about $51^{\circ} \mathrm{C}$, which was measured under the most intensive treatment conditions $(30 \mathrm{kV} / \mathrm{cm}, 100 \mathrm{~kJ} / \mathrm{kg}$ ) for an inlet temperature of $45^{\circ} \mathrm{C}$. Additionally, the suspension was maintained at this temperature for only 2-3 s before being collected in plastic tubes and immediately placed in a water-ice bath.

The positive impact of the combined PEF-heat treatment on the extraction of valuable compounds from algae cell suspensions was previously observed by few other scientists, even though, to date, no previous works dealt with the use of bipolar pulses. For example, Postma et al. (2016) studied the effect of PEF treatment $\left(17.1 \mathrm{kV} / \mathrm{cm} ; 100 \mathrm{~kJ} / \mathrm{kg}_{\text {susp }}\right)$ combined with mild heating $\left(25-65^{\circ} \mathrm{C}\right)$ on the extractability of valuable compounds from $C$. vulgaris cells suspensions. They observed only a slight positive interaction between PEF and temperature on the recovery of WSP when the temperature was increased in the range $25-45^{\circ} \mathrm{C}$, leading to a maximum extraction yield of $4.4 \%$. The analysis of the carbohydrates in the supernatant, instead, revealed the existence of a clear synergistic effect of the combined treatment, but only when the processing temperature was increased from 45 to $55^{\circ} \mathrm{C}$, leading to an increase in carbohydrates yield from 25 to $39 \%$ of total biomass carbohydrate content. With regard to the extraction of pigments, Luengo et al. (2015) found that an increase of the temperature of PEF treatment $(25 \mathrm{kV} / \mathrm{cm}, 150$ $\mu \mathrm{s})$ of C. vulgaris from 10 to $40^{\circ} \mathrm{C}$ increased the concentration of lutein in the extracts from 451 to $753 \mu \mathrm{g} / \mathrm{g}_{\mathrm{DW}}$. Similarly, Martinez et al. (2017) found that the increment of the processing temperature from 10 to $40^{\circ} \mathrm{C}$ during PEF treatment $(25 \mathrm{kV} / \mathrm{cm}$, $150 \mu \mathrm{s})$ of $A$. platensis cells suspensions remarkably increased the extraction yield of C-phycocyanin up to a maximum value of $16.0 \% \mathrm{DW}$.

Interestingly, in all these works it was stated that mild heating of algae suspension contributes not only to enhance the diffusivity and solubility of intracellular compounds in water but also to make the lipid bilayer of the cell membrane more susceptible for breakdown under the PEF treatment (Timmermans et al., 2014; Luengo et al., 2015; Postma et al., 2016; Martinez et al., 2017). This would also explain the synergistic effect of the combined PEFheat treatment on the extractability of water-soluble compounds observed in the present work.

However, although the hurdle approach revealed a positive interaction between electric field and moderate temperatures, the results of Figure 5 show that the maximum amount of the target compounds released after the combined treatment still remained lower than that achieved with the benchmark HPH process. This is somehow consistent with the findings previously reported by other scientists. For example, when comparing the extraction yield of water-soluble compounds achieved by the combined PEF-heat treatment of microalgae with those obtained after complete cell disruption by bead milling, Postma et al. (2016) estimated that about $10 \%$ of the total content of WSP was extracted from C. vulgaris cells, whereas Martinez et al. (2017) calculated a $70 \%$ of the total content of C-PC from A. platensis cells. This suggests that the combination of PEF with mild heating treatment is effective in the selective release of $\mathrm{CH}, \mathrm{C}-\mathrm{PC}$, and WSP of small molecular weight compounds, while the extraction of larger compounds more bounded to intracellular structure, would require the application of more effective cell disruption techniques than PEF, such as bead milling or HPH (Postma et al., 2016; Martinez et al., 2017; Pataro et al., 2017; Carullo et al., 2018). In this latter case, however, higher recovery yields would likely be achieved at expenses of lower purity of the extracts. This is clearly shown by the results presented in Figure 5D, which highlights that, regardless of the processing temperature and pulse polarity, the purity of the C-PC extract from A. platensis cells suspensions upon the application of PEF pre-treatment was always higher (0.71-0.89) than that estimated for the extracts obtained after treating the cells with HPH (0.53), which is consistent with the finding of Martinez et al. (2017). Interestingly, since a C-PC purity of 0.7 is required for food-grade products (Vernès et al., 2015), the C-PC extract obtained after PEF treatment could potentially be used for food application without the need for further refining stages (Rito-Palomares et al., 2001).

\section{Energy Efficiency Analysis}

After demonstrating that PEF treatment $(20 \mathrm{kV} / \mathrm{cm}$, $100 \mathrm{~kJ} / \mathrm{kg}_{\text {susp }}$ ), especially when using monopolar pulses combined with moderate heating $\left(35^{\circ} \mathrm{C}\right)$, is effective for promoting the selective extraction of water-soluble compounds from A. platensis cells suspensions, in the last step of this work we also evaluated its feasibility in terms of energy consumption. 
Results of Table 1 highlight the comparison among the different cell disruption techniques investigated (PEF $\mathrm{M}$ and PEF B at processing temperature of 25 or $35^{\circ} \mathrm{C}$, mild heating at $35^{\circ} \mathrm{C}$, combined PEF (mono or bipolar)-heating $\left(35^{\circ} \mathrm{C}\right.$ ), and $\mathrm{HPH}$ ) in terms of the energy consumed to extract $1 \mathrm{~kg}$ of the target water-soluble compounds (WSP, $\mathrm{CH}, \mathrm{C}-\mathrm{PC}$ ) from A. platensis cells. Overall, the estimated energy consumptions show that PEF is more efficient than HPH in a manner dependent on the type of compounds to be extracted and processing conditions applied. In particular, PEF M applied at room temperature enabled the recovery of either $\mathrm{CH}$ and C-PC at comparable yields with $\mathrm{HPH}$, but with higher purity and significantly lower energy consumption, with the perspective of facilitating purification operations in downstream processes. In the case of WSP, instead, PEF $M$ at room temperature showed only a slightly higher energy efficiency than $\mathrm{HPH}$, likely due to the limited capacity of the simply electroporated cells to release a significant amount of large molecular-weight proteins in comparison with the cells completely disintegrated by HPH treatment. As expected, the lower extraction yields of WSP and C-PC achieved upon the application of PEF B at room temperature than $\mathrm{PEF} M$, required higher energy consumption for the recovery of these water-soluble compounds. In comparison with HPH, PEF B was more energetically efficient only in the case of $\mathrm{CH}$ recovery.

The mild heating of the algae suspension at $35^{\circ} \mathrm{C}$ without any PEF treatment scarcely affected the release of the target watersoluble compounds, requiring the highest expenditures of energy. Interestingly, the combined PEF M-temperature treatment required comparable energy consumptions per unit mass of WSP and $\mathrm{CH}$ to those required by PEF $\mathrm{M}$ at room temperature, while showing a significantly lower energy consumption for the recovery of C-PC. These results can be explained by the synergistic effect of the combined treatment on the extractability of intracellular compounds. A similar trend was observed when PEF B was combined with moderate heating, which appeared more energetically efficient than HPH for the recovery of only $\mathrm{CH}$ and $\mathrm{C}-\mathrm{PC}$.

TABLE 1 | Specific energy consumptions ( $E C$, in $\mathrm{kWh} / \mathrm{kgDW}$ ) of the different cell disruption techniques for the recovery of a unit mass of target compounds (WSP, water-soluble proteins; C-PC, C-phycocyanin; $\mathrm{CHO}$, carbohydrates) from A. platensis microalgae suspensions.

\begin{tabular}{|c|c|c|c|}
\hline \multirow[t]{2}{*}{ Disruption method } & \multicolumn{3}{|c|}{$\begin{array}{c}\text { Specific energy } \\
\text { consumption }\left(\mathbf{k W h} / \mathrm{kg}_{\mathrm{DW}}\right)\end{array}$} \\
\hline & WSP & C-PC & $\mathrm{CH}$ \\
\hline $\operatorname{PEF} M\left(T_{\mathbb{N}}=25^{\circ} \mathrm{C}\right)$ & 8.1 & 65.7 & 13.7 \\
\hline $\operatorname{PEF} B\left(T_{I N}=25^{\circ} \mathrm{C}\right)$ & 10.8 & 120.1 & 15.9 \\
\hline Mild heating $\left(T_{\mathbb{N}}=35^{\circ} \mathrm{C}\right)$ & 79.6 & 401.3 & 443.9 \\
\hline Mild heating $\left(T_{I N}=35^{\circ} \mathrm{C}\right)+$ PEF $M$ & 8.4 & 47.9 & 17.1 \\
\hline Mild heating $\left(T_{\mathbb{N}}=35^{\circ} \mathrm{C}\right)+$ PEF $B$ & 12.1 & 100.1 & 20.1 \\
\hline $\mathrm{HPH}$ & 10.5 & 110.5 & 53.7 \\
\hline
\end{tabular}

PEF $M$ and PEF B indicate the PEF treatment $(20 \mathrm{kV} / \mathrm{cm}, 100 \mathrm{~kJ} / \mathrm{kg})$ with mono and bipolar pulses (delay time $=10 \mu \mathrm{s}$ ), respectively. HPH treatment conditions: $P=150 \mathrm{MPa} ; n_{P}=3$.
These results are consistent with findings previously reported by other scientists when comparing PEF and HPH in terms of energy consumed to extracts water-soluble compounds, even though from different algae cells and focusing only on monopolar pulses during treatment at room temperature. For example, when Grimi et al. (2014) and Carullo et al. (2018) compared PEF and HPH in terms of the energy consumed to extract $1 \mathrm{~kg}$ of carbohydrates or proteins from Nannochloropsis spp. and C. vulgaris microalgae, they found that PEF was slightly less energetically efficient than HPH for the recovery of WSP, while showed lower energy consumption than HPH for the recovery of $\mathrm{CH}$.

Further studies are required to comparatively investigate the effect of PEF and HPH on microalgae strain characterized by different cell envelops, as well as processing biomass with higher solid concentrations than the diluted suspension used in this work, since those parameters could significantly affect the energy efficiency of both PEF and HPH treatment (Goettel et al., 2013; Yap et al., 2015).

\section{CONCLUSION}

Results obtained in this study have demonstrated the potential of PEF technology to intensify the selective release of watersoluble compounds (WSP, CH, C-PC) from A. platensis cell suspensions.

The extraction efficiency of intracellular compounds by PEF treatment depended on electrical parameters such as electric field strength, energy input, pulse polarity, and delay time between pulses of opposite polarity. The application of bipolar pulses resulted to be less effective in the permeabilization of the membranes of algae cells and the subsequent recovery of the target intracellular compounds than the usage of monopolar pulses, at least in the range of operative conditions investigated in this work. However, the optimization of the time delay between two consecutive pulses of opposite polarity appeared crucial to increase the probability of membrane permeabilization and the extraction efficiency of bipolar pulses. Therefore, further studies are needed in order to better elucidate the effect of bipolar pulses and the role played by the delay time and pulse width on the algae cell permeabilization. Improving the efficacy of bipolar pulses in the electroporation process could be very interesting, since its use will enable to drastically limit the occurrence of undesired electrochemical reactions (e.g., corrosion, electrolysis) at the electrode interface when monopolar pulses are applied (Pataro and Ferrari, 2020).

Interestingly, the use of PEF in a hurdle approach with mild heating of the biomass at $35^{\circ} \mathrm{C}$ remarkably enhanced the extractability of intracellular compounds showing a clear synergistic effect, regardless of the pulse polarity. In comparisons with the highly disruptive effect of HPH treatment, PEF enabled the selective release of low molecular weight WSP, $\mathrm{CH}$ and especially the recovery of high purity $(>0.7)$ C-PC extract, lowering the energy consumption and without the formation of cell debris, which might facilitate the subsequent downstream purification operations. 


\section{DATA AVAILABILITY STATEMENT}

All datasets generated for this study are included in the article/supplementary material.

\section{AUTHOR CONTRIBUTIONS}

GP and GF contributed to the conception and design of the study. DC was in charge of performing the chemical and statistical analysis and wrote the first draft of the manuscript. GP, FD, and

\section{REFERENCES}

Abelde, J., Betancourt, L., Torres, E., Cid, A., and Barwell, C. (1998). Purification and characterization of phycocyanin from the marine cyanobacteriums Synechococcus sp. IO9201. Plant Sci. 136, 109-120. doi: 10.1016/S0168-9452(98) 00113-117

Aouir, A., Amiali, M., Kirilova-Gachovska, T., Benchabane, A., and Bitam, A. (2015). "The effect of pulsed electric field (PEF) and ultrasound (US) technologies on the extraction of phycopiliproteins from Arthrospira platensis," in Proceedings of the Canada International Humanitarian Technology Conference, Ottawa, ON.

Bennett, A., and Bogorad, L. (1973). Complementary chromatic adaptation in a filamentous blue-green alga. J. Cell Biol. 58, 419-435. doi: 10.1083/jcb.58.2.419

Beveridge, J. R., MacGregor, S. J., Marsili, L., Anderson, J. G., Rowan, N. J., and Farish, O. (2002). Comparison of the effectiveness of biphase and monophase rectangular pulses for the inactivation of micro-organisms using pulsed electric fields. IEEE Trans. Plasma Sci. 30, 1525-1531. doi: 10.1109/tps.2002.804204

Carullo, D., Abera, B. D., Casazza, A. A., Donsì, F., Perego, P., Ferrari, G., et al. (2018). Effect of pulsed electric fields and high pressure homogenisation on the acqueous extraction of intracellular compounds from the microalgae Chlorella vulgaris. Algal Res. 31, 60-69. doi: 10.1016/j.algal.2018.01.017

Chaiklahan, R., Chirasuwan, N., and Bunnag, B. (2012). Stability of phycocyanin extracted from Spirulina sp.: influence of temperature, $\mathrm{pH}$ and preservatives. Process Biochem. 47, 659-664. doi: 10.1016/j.procbio.2012.01.010

Chang, D. C. (1989). Cell poration and cell fusion using an oscillating electric field. Biophys. J. 56, 641-652. doi: 10.1016/S0006-3495(89)82711-82710

DuBois, M., Gilles, K. A., Hamilton, J. K., Rebers, P. A., and Smith, F. (1956). Colorimetric method for determination of sugars and related substances. Anal. Chem. 28, 350-356. doi: 10.1021/ac60111a017

Evrendilek, G. A., and Zhang, Q. (2005). Effects of pulse polarity and pulse delaying time on pulsed electric fields-induced pasteurization of E. coli O157:H7. J. Food Eng. 68, 271-276. doi: 10.1016/j.jfoodeng.2004.06.001

Fernández-Rojas, B., Hernández-Juárez, J., and Pedraza-Chaverri, J. (2014). Nutraceutical properties of phycocyanin. J. Funct. Foods 11, 375-392. doi: 10. 1016/j.jff.2014.10.011

Folin, O., and Ciocalteau, V. (1927). On tyrosine and tryptophane determinations in proteins. J. Biol. Chem. 73, 627-650.

Garcia, D., Gomez, N., Mañas, P., Raso, J., and Pagan, R. (2007). Pulsed electric fields cause bacterial envelopes permeabilization depending on the treatment intensity, the treatment medium $\mathrm{pH}$ and the microorganism investigated. Int. J. Food Microbiol. 113, 219-227. doi: 10.1016/j.ijfoodmicro.2006.07.007

Geada, P., Rodriguez, R., Loureiro, L., Pereira, R., Fernandez, B., Teixeira, J. A., et al. (2018). Electrotechnologies applied to microalgal biotechnologyapplications, techniques and future trends. Renew. Sust. Environ. Rev. 94, 656-668. doi: 10.1016/j.rser.2018.06.059

Goettel, M., Eing, C., Gusbeth, C., Straessner, R., and Frey, W. (2013). Pulsed electric field assisted extraction of intracellular valuables from microalgae. Algal Res. 2, 401-408. doi: 10.1016/j.algal.2013.07.004

Golberg, A., Sack, M., Teissie, J., Pataro, G., Pliquett, U., Saulis, G., et al. (2016). Energy-efficient biomass processing with pulsed electric fields for bioeconomy and sustainable development. Biotechnol. Biofuels 9, 1-22. doi: 10.1201/ 9780429133459-1
DC performed the experiments. GF supervised the study. All authors contributed to manuscript revision, read and approved the submitted version.

\section{ACKNOWLEDGMENTS}

We wish to thank the ATI Biotech Company for providing A. platensis biomass and Dr. Mariarosa Scognamiglio for her invaluable help with SEM analyses.

Grimi, N., Dubois, A., Marchal, L., Jubeau, S., Lebovka, N. I., and Vorobiev, E. (2014). Selective extraction from microalgae Nannochloropsis sp. using different methods of cell disruption. Bioresour. Technol. 153, 254-259. doi: 10.1016/j. biortech.2013.12.011

Günerken, E., D’Hondt, E., Eppink, M. H. M., Garcia-Gonzales, L., Elst, K., and Wijffels, R. H. (2015). Cell disruption for microalgae biorefineries. Biotechnol. Adv. 33, 243-260. doi: 10.1016/j.biotechadv.2015.01.008

Han, S.-F., Jin, W., Yang, Q., Abomohra, A. E.-F., Zhou, X., Tu, R., et al. (2019). Application of pulse electric field pretreatment for enhancing lipid extraction from Chlorella pyrenoidosa grown in wastewater. Renew. Environ. 133, 233-239. doi: 10.1016/j.renene.2018.10.034

Jaeschke, D. P., Domeneghini Mercali, G., Ferreira Marczak, L. D., Müller, G., Frey, W., and Gusbeth, C. (2019). Extraction of valuable compounds from Arthrospira platensis using pulsed electric field treatment. Bioresour. Technol. 283, 207-212. doi: 10.1016/j.biortech.2019.03.035

Lowry, O. H., Rosebrough, N. J., Farr, A. L., and Randall, R. J. (1951). Protein measurement with the Folin phenol reagent. J. Biol. Chem. 193, 265-275.

Lu, H. K., Hsieh, C. C., Hsu, J. J., Yang, Y. K., and Chou, H. N. (2006). Preventive effects of Spirulina platensis on skeletal muscle damage under exercise-induced oxidative stress. Eur. J. Appl. Physiol. 98, 220-226. doi: 10.1007/s00421-0060263-260

Luengo, E., Mart $\iota$ nez, J. M., Bordetas, A., Alvarez, I., and Raso, J. (2015). Influence of the treatment medium temperature on lutein extraction assisted by pulsed electric fields from Chlorella vulgaris. Innov. Food Sci. Emerg. Technol. 29, 15-22. doi: 10.1016/j.ifset.2015.02.012

Lupatini, A. L., Colla, L. M., Canan, C., and Colla, E. (2016). Potential application of microalgae Spirulina platensis as a protein source. J. Sci. Food Agric. 97, 724-732. doi: $10.1002 /$ jsfa.7987

Martinez, J. M., Delso, C., Alvarez, I., and Raso, J. (2020). Pulsed electric fieldassisted extraction of valuable compounds from microorganisms. Compr. Rev. Food Sci. Food Saf. 19, 530-552. doi: 10.1111/1541-4337.12512

Martinez, J. M., Luengo, E., Saldana, G., Alvarez, I., and Raso, J. (2017). Cphycocyanin extraction assisted by pulsed electric field from Artrosphira platensis. Food Res. Int. 99, 1042-1047. doi: 10.1016/j.foodres.2016. 09.029

Parniakov, O., Barba, F. J., Grimi, N., Marchal, L., Jubeau, S., Lebovka, N., et al. (2015a). Pulsed electric field and $\mathrm{pH}$ assisted selective extraction of intracellular components from microalgae Nannochloropsis. Algal Res. 8, 128-134. doi: 10. 1016/j.algal.2015.01.014

Parniakov, O., Barba, F. J., Grimi, N., Marchal, L., Jubeau, S., Lebovka, N., et al. (2015b). Pulsed electric field assisted extraction of nutritionally valuable compounds from microalgae Nannochloropsis spp. using the binary mixture of organic solvents and water. Innov. Food Sci. Emerg. Technol. 27, 79-85. doi: 10.1016/j.ifset.2014.11.002

Pataro, G., Carullo, D., and Ferrari, G. (2019). PEF-assisted supercritical $\mathrm{CO}_{2}$ extraction of pigments, from microalgae Nannochloropsis oceanica in a continuous flow system. Chem. Eng. Trans. 74, 97-102. doi: 10.3303/ CET1974017

Pataro, G., and Ferrari, G. (2020). "Limitations of pulsed electric field utilization in food industry," in Pulsed Electric Field to Obtain Healthier and Sustainable Food for Tomorrow, eds F. Barba, O. Parniakov, and A. Wiktor (London: Academic Press), 283-310. doi: 10.1016/b978-0-12-816402-0.00013-6 
Pataro, G., Goettel, M., Straessner, R., Gusbeth, C., Ferrari, G., and Frey, W. (2017). Effect of PEF treatment on extraction of valuable compounds from Microalgae C. vulgaris. Chem. Eng. Trans. 57, 67-72. doi: 10.3303/CET1757012

Phong, W. N., Show, P. L., Ling, T. C., Juan, J. C., Ng, E.-P., Chang, J.-S., et al. (2017). Mild cell disruption methods for bio-functional proteins recovery from microalgae-recent developments and future perspectives. Algal Res. 31, 506-516. doi: 10.1016/j.algal.2017.04.005

Poojary, M. M., Barba, F. J., Aliakbarian, B., Donsì, F., Pataro, G., Dias, D. A., et al. (2016). Innovative alternative technologies to extract carotenoids from microalgae and seaweeds. Mar. Drugs 14, 214. doi: 10.3390/md14110214

Postma, P. R., Pataro, G., Capitoli, M., Barbosa, M. J., Wijffels, R. H., Eppink, M. H. M., et al. (2016). Selective extraction of entracellular components from the microalga Chlorella Vulgaris by combined pulsed electric field-temperature treatments. Bioresour. Technol. 203, 80-88. doi: 10.1016/j.biortech.2015.12.012

Qin, B. L., Zhang, Q., Swanson, B. G., and Pedrow, P. D. (1994). Inactivation of microorganism by different pulsed electric fields of different voltage waveforms. IEEE T. Ind. App. 1, 1047-1057. doi: 10.1109/94.368658

Rito-Palomares, M., Nunez, M., and Amador, D. (2001). Practical application of aqueous two-phase systems for the development of a prototype process for c-phycocyanin recovery from Spirulina maxima. J. Chem. Technol. Biotechnol. 76, 1273-1280. doi: 10.1002/jctb.507

Safi, C., Charton, M., Ursu, A. V., Laroche, C., Zebib, B., Pontalier, P.-Y., et al. (2014). Release of hydro-soluble microalgal proteins using mechanical and chemical treatments. Algal Res. 3, 55-60. doi: 10.1016/j.algal.2013.11.017

Safi, C., Frances, C., Ursu, A. V., Laroche, C., Pouzet, C., Vaca-Garcia, C., et al. (2015). Understanding the effect of cell disruption methods on the diffusion of Chlorella vulgaris proteins and pigments in the aqueous phase. Algal Res. 8, 61-68. doi: 10.1016/j.algal.2015.01.002

Saldaña, G., Álvarez, I., Condón, S., and Raso, J. (2014). Microbiological aspects related to the feasibility of PEF technology for food pasteurization. Crit. Rev. Food Sci. Nutr. 54, 1415-1426. doi: 10.1080/10408398.2011.638995

Silve, A., Papachristou, I., Wustner, R., Strabner, R., Schirmer, M., Leber, K., et al. (2018). Extraction of lipids from wet microalga Auxenochlorella protothecoides using pulsed electric field treatment and ethanol-hexane blends. Algal Res. 29, 212-222. doi: 10.1016/j.algal.2017.11.016

Sweeney, D. C., Reberšek, M., Dermol, J., Rems, L., Miklavčič, D., and Davalos, R. V. (2016). Quantification of cell membrane permeability induced bymonopolar and high-frequency bipolar bursts of electrical pulses. Biochim. Biophys. Acta 1858, 2689-2698. doi: 10.1016/j.bbamem.2016.06.024

Timmermans, R. A. H., Nierop Groot, M. N., Nederhoff, A. L., van Boekel, M. A. J. S., Matser, A. M., and Mastwijk, H. C. (2014). Pulsed electric field processing of different fruit juices: impact of $\mathrm{pH}$ and temperature on inactivation of spoilage and pathogenic micro-organisms. Int. J. Food Microbiol. 173, 105-111. doi: 10.1016/j.ijfoodmicro.2013.12.022

Vernès, L., Granvillain, P., Chemat, F., and Vian, M. (2015). Phycocyanin from Arthrospira platensis. Production, extraction and analysis. Curr. Biotechnol. 4. doi: 10.2174/2211550104666151006002418

Yap, B. H. J., Dumsday, G. J., Scales, P. J., and Martin, G. J. O. (2015). Energy evaluation of algal cell disruption by high pressure homogenization. Bioresour. Technol. 184, 280-285. doi: 10.1016/j.biortech.2014.11.049

Zbinden, M. D. A., Sturm, B. S., Nord, R. D., Carey, W. J., Moore, D., Shinogle, H., et al. (2013). Pulsed electric field (PEF) as an intensification pretreatment for greener solvent lipid extraction from microalgae. Biotechnol. Bioeng. 110, 1605-1615. doi: 10.1002/bit.24829

't Lam, G. P., Postma, P. R., Fernandes, D. A., Timmermans, R. A. H., Vermue, M. H., Barbosa, M. J., et al. (2017a). Pulsed electric field for protein release of the microalgae Chlorella vulgaris and Neochloris oleoabundans. Algal Res. 24, 181-187. doi: 10.1016/j.algal.2017.03.024

't Lam, G. P., van der Kolk, J. A., Chordia, A., Marian, H., Vermuë, M. H., Olivieri, G., et al. (2017b). Mild and selective protein release of cell wall deficient microalgae with pulsed electric field. ACS Sustainable Chem. Eng. 5, 6046-6053. doi: 10.1021/acssuschemeng.7b00892

Conflict of Interest: The authors declare that the research was conducted in the absence of any commercial or financial relationships that could be construed as a potential conflict of interest.

Copyright (C) 2020 Carullo, Pataro, Donsi and Ferrari. This is an open-access article distributed under the terms of the Creative Commons Attribution License (CC BY). The use, distribution or reproduction in other forums is permitted, provided the original author(s) and the copyright owner(s) are credited and that the original publication in this journal is cited, in accordance with accepted academic practice. No use, distribution or reproduction is permitted which does not comply with these terms. 